\title{
GAY'S ACCEPTANCE ON HIV POSITIVE STATUS: A SYSTEMATIC REVIEW
}

\author{
Popy Apriyanti, Dhesi Ari Astuti, Yekti Satriyandari
}

Universitas ‘Aisyiyah Yogyakarta

\begin{abstract}
Background: Centers for Disease Control and Prevention (CDC) found that the rate of HIV infection among gays is 44 times as many as the rate among heterosexual men. HIV infection/AIDS has been accompanied with fear, ignorance, and denial, leading to stigmatization and discrimination against people living with HIV/AIDS and their families. This study aimed to systematically review gay's acceptance on HIV positive status.

Subjects and Method: A systematic review was conducted by searching articles from PubMed and ProQuest databases. The inclusion criteria were: (1) Gay or homosexual or man who have sex with man with HIV/AIDS status; (2) Full text; (3) Articles published from 2008 to 2018; and (4) International journal. Appraisal studies were using the Critical Appraisal Skills Program (CASP), and synthesis methods using a modification of PEOS.

Results: Articles met the inclusion criteria reported that: (1) Gay with HIV positive status were experiencing anxiety disorder, feeling afraid of losing their partners and closest people; (2) Health care providers and HIV counselors were not consistent in providing health services; (3) Stigma and discrimination in the community; and (4) Support and role of gay/MSM in the prevention of HIV/AIDS. Most gays with HIV positive showed the same response of anxiety, shock, distrust, and refusal. Over time, the gays accepted their positive HIV status in the form of resignation and courage. Most of gays have not revealed their HIV status, especially to their partners and families because they are afraid of rejection and stigma.
\end{abstract}

Conclusion: Over time, the gays accepted their positive HIV status in the form of resignation and courage.

Keywords: gay, homosexual, HIV/AIDS

\section{Correspondence:}

Popy Apriyanti. Universitas 'Aisyiyah Yogyakarta. Jl. Ringroad Barat No. 63, Nogotirto, Gamping, Nogotirto, Sleman, Yogyakarta, Indonesia. Email: Popy.Apriyanti@gmail.com. Mobile: 081271888256. 